ACTA THERIOLOGICA

Vol. 28, 9: 159-170, 1983

\title{
Chromosomes of Some Species of Vespertilionid Bats. I. Banding Patterns of Eptesicus serotinus Chromosomes
}

\author{
Stanisław FEDYK \& Andrzej L. RUPRECHT
}

\begin{abstract}
Fedyk S. \& Ruprecht A. L., 1983: Chromosomes of some species of vespertilionid bats. I. Banding patterns of Eptesicus serotinus chromosomes. Acta theriol., 28, 9: 159-170 [With 2 Tables \& Plate VII]

Conventional and differential staining revealed that the karyotype of Eptesicus serotinus (Schreber, 1774) from the Białowieża population consists of 24 pairs of telocentric autosomes. Only sex chromosomes have two arms; the $X$-chromosome is submetacentric and similar in size to that of the largest pair of autosomes, while the $Y$-chromosome is submetacentric and of the size of the two smallest pairs of autosomes. Thus, the karyotype of E. serotinus from north-eastern Poland has the form $2 \mathrm{~N}=50, \mathrm{NFa}=48$. The banded karyotype of $E$. serotinus from this population was compared with analogous karyotypes of two North American species, Eptesicus fuscus (Palisot de Beauvois, 1796) and Eptesicus lynni Shamel, 1945 , also with $2 \mathrm{~N}=50, \mathrm{NFa}=48$. A complete homology has been found between the chromosomes of $E$. serotinus and those of E. fuscus and E. lynni.

[Mammals Res. Inst., Polish Acad. Sci., 17-230 Białowieża, Poland].
\end{abstract}

\section{INTRODUCTION}

The application of differential staining permits the distinct indentification of individual chromosomes. By means of this technique it is possible to recognize homologous chromosomes or segments of chromosomes of related species. This is important since translocations of whole chromosome arms (centric fusions or dissociations, i.e., the so-called Robertsonian processes) are a frequent mechanism of the differentiation of chromosome patterns in mammals. We already know (Capanna, 1968a, b; Capanna \& Civitelli, 1970) that the Robertsonian processes played an important part in the evolution of the karyotypes of vespertilionid bats; most species of this family are characterized by a constant number of autosome arms $(\mathrm{NFa})$, which is equal to 50 or 48 , while the number of chromosomes $(2 \mathrm{~N})$ is very variable (Capanna \& Civitelli, 1970; Zima, 1978).

The earlier studies carried out on conventionally stained material revealed that different species of the genus Eptesicus have a very ancestral chromosome pattern: $2 \mathrm{~N}=50$ and all autosomes telocentric $(\mathrm{NFa}=48)$. This is the case of Eurasian species such as E. serotinus, E. nilssoni (Fedyk \& Fedyk, 1970; Baker et al., 1974; Ando et al., 1977; 
Zima, 1978; Tsuchiya, 1979), and also American species such as E. fuscus, E. lynni, E. andinus, E. brasiliensis, E. diminutus and E. guadeloupensis (Baker \& Patton, 1967; Baker \& Lopez, 1970; Baker \& Jordan, 1970; Genoways \& Baker, 1975; Williams, 1978; Bickham, 1979a). An identical ancestral karyotype occurs in the African species E. hottentotus. A deviation from this ancestral chromosome pattern has so far been recorded only in the African species E. capensis $(2 \mathrm{~N}=32 ; \mathrm{NFa}=50)$ (Peterson \& Nagorsen, 1975).

Most of the species belonging to genera of vespertilionid bats other than Eptesicus are characterized by 50 autosome arms, the number of chromosomes ranging from 26 to 46 . As differential staining shows, in North American species of the genera Myotis, Pipistrellus, Plecotus, Idionycteris, Lasiurus, Lasionycteris, Rhogeëssa, Antrozous, and Nycticeius, and in Palaearctic Miniopterus it is easy to identify arms of biarmed chromosomes analogous with those of Eptesicus (Bickham, 1979a). Hence, the earlier suggestions of Bovey (1949) that Robertsonian processes were of great importance in the evolution of the chromosome pattern of vespertilionid bats have been confirmed.

Bickham $(1979 \mathrm{a}, \mathrm{b})$ gave a detailed description of the banding pattern of North American vespertilionid species and developed a uniform nomenclature of arms or of telocentric chromosomes in vespertilionid bats; he numbered the autosomes of Eptesicus from 1 to 25, giving number $16 / 17$ to one of the small chromosomes. This was the biarmed chromosome with an arm combination of 16 and 17, occurring in many species of vespertilionid bats. Eptesicus fuscus and E. lynni have no separate telocentric chromosomes nos 16 and 17, while the chromosome homologous with the biarmed chromosome no 16/17. (occurring, e. g., in Myotis) is the telocentric chromosome no "16/17", which differs in a pericentric inversion.

The aim of the present work was to find whether or not the banding pattern of Eptesicus serotinus completely corresponds to the banding pattern of North American species of the genus Eptesicus. So far among four European Eptesicus only the banding patterns of E. nilssoni have been described (Zima, 1982).

\section{MATERIAL AND METHODS}

Four males and one female of Eptesicus serotinus captured in 1981 in Białowieża (Białystok region, north-eastern Poland) were used for the present analysis. Chromosome preparations of the spleen and marrow were made using the direct preparation technique. The animals were treated in vivo with colchicine for 30-40 minutes. G-banding was obtained on air-dried preparations that were 
etched with trypsin, and stained with Giemsa solution by the Seabright (1971) method. Metaphase plates with different degrees of chromosome contraction were selected for analysis. Banding patterns of particular chromosome pairs were compared with those of North American vespertilionid bats (Bickham, 1979a, b).

\section{RESULTS}

The karyotype of Eptesicus serotinus (Fig. 1) consisted of 24 telocentric autosomes. Only the sex chromosomes had two arms; the $\mathrm{X}$-chromosome was submetacentric and of a size approaching that of the largest autosome pair, the $Y$-chromosome also being submetacentric but of the size of the two smallest autosomes. Thus $2 \mathrm{~N}=50, \mathrm{NFa}=48$.

\subsection{The Homology of Chromosomes in E. serotinus and North American Species of Eptesicus}

The development of a standard system for the identification of autosome arms in vespertilionid bats (Bickham \& Baker, 1977; Bickham, 1979a, b), enables comparative studies to be carried out on the chromosomes of these groups of animals. The methods for differential staining of chromosomes permit an exact identification even of particular segments. It should be noted, however, that it is not always possible to compare all bands in detail. This limitation mainly results from the fact that even small differences in the degree of chromosome shrinkage give rise to the appearance of additional bands, or to the merging of neighbouring bands into larger blocks. However, the identification of particular chromosome arms on the basis of specific banding patterns is sufficient to decide the homology of these elements.

In this study the banding pattern of E. serotinus was compared with that of the North American species Eptesicus fuscus and E. lynni, which also have $2 \mathrm{~N}=50, \mathrm{NFa}=48$ (Bickham, 1979a).

The banded karyotype of E. serotinus is shown in Fig. 2. Chromosome no 1 has five dark bands more or less evenly distributed along the chromosome. Also chromosome no 2 has five bands, but three much larger, light interbands constitute a distinctive feature. Chromosome no 3 is characterized by a block of dark bands in the median part and also by additional, thin and much lighter bands at both ends. Chromosome no 4 has a large light interband in the median position and two thin bands at each end. Chromosome no 5 passesses three bands in the centromere region, which form a compact block in the North American species (probably an effect of chromosome contraction), and one band in the terminal region. Chromosome no 6 has two bands in the terminal region, and two bands interspaced with light areas in the centromere 
region, more or less in the median part of the chromosome. The banding pattern of these six chromosome pairs is identical to that of E. fuscus and E. lynni.

The chromosomes of pairs 7 and 8 are similar to each other. They have distinct bands in the median position but additional thinner bands differentiate them. The chromosomes of pair 9 have three bands and no bands in the centromere region. Chromosome no 10 has three distinct bands. These four pairs possess a banding pattern identical to that of the North American species.

The characteristic feature of chromosomes no 11 is one thick band in the median region and another at the centromere. In the North American forms this pair is highly variable. Nevertheless, such a banding pattern can also be observed (cf. Fig. 3 in Bickham, 1979a), though usually an additional band occurs in the terminal region.

Chromosomes no 12 have two bands and are completely homologous with those of the North American forms.

Chromosomes no 13 of the North American forms also have variable banding patterns. A characteristic dark band at the centromere was also identified in the Polish bats.

Three bands characteristic of chromosomes no 14 also occur in E. serotinus. The banding pattern of chromosomes no 15 is relatively poorly defined in the American forms. In Myotis nigricans Bickham (1979b) found four bands on this chromosome. In Eptesicus serotinus only two rather weakly staining bands were identified, which may correspond to the band at the centromere and to the band 3 , located in the median region, in $M$. nigricans.

Chromosome no $16 / 17$ in E. serotinus is acrocentric and has two bands positioned like those in the American Eptesicus. The homology of this element is not a matter of much doubt.

Chromosomes no 18 and 19 have one clear-cut band. In addition, pair 18 has single weakly staining and thinner bands at both ends, and pair 19 has one band at the centromere. This one band stains weakly in E. serotinus.

Chromosome pair no 20 has two bands positioned like the corresponding bands in the North American species. Pair 21 has one distinct band in E. fuscus (Bickham, 1979a) and three distinct bands in Myotis thysanodes (Bickham, 1979b). In E. serotinus three bands were recorded.

Four pairs of the smallest autosomes (designated nos 22 to 25) are difficult to distinguish. Only chromosome no 22 has two distinct bands, while the remaining three pairs have single ones. A similar picture was observed in the North American species.

The banding pattern of the $X$-chromosome in E. serotinus is entirely 
homologous with that of $E$. fuscus. The $Y$-chromosome in E. serotinus has no bands at all, while in the North American Myotis, Bickham $(1979 \mathrm{~b})$ identified two thin bands. It should be stated, therefore, that the chromosomes of $E$. serotinus are completely homologous with those of $E$. fuscus and E. lynni. There may be some doubt only about the banding pattern of small chromosomes, most likely arising from different contraction of the chromosomes compared. However, no differences in translocation were found between E. serotinus and the two North American species, E. fuscus and E. lynni.

\section{DISCUSSION}

So far, the chromosomes of 12 species of the genus Eptesicus have been described (Table 1). Most of them have an identical, very primitive karyotype made up of 50 chromosomes, of which all autosomes are

Table 1

Data on chromosomes of the genus Eptesicus.

\begin{tabular}{llll}
\hline \multicolumn{1}{c}{ Species } & 2N & NFa & \multicolumn{1}{c}{ References } \\
\hline E. serotinus & 50 & 48 & Fedyk \& Fedyk, 1970 \\
& 50 & 48 & Baker et al., 1974 \\
E. nilssoni & 50 & $50^{1}$ & Zima, 1978 \\
E. parvus & 50 & $48^{2}$ & Ando et al., 1977 \\
E. hottentotus & 50 & $50^{1}$ & Zima, 1978 \\
E. capensis & 50 & 48 & Tsuchiya, 1979 \\
E. fuscus & 50 & 48 & Peterson \& Nagorsen, 1975 \\
& 32 & 50 & Peterson \& Nagorsen, 1975 \\
& 50 & 48 & Baker \& Patton, 1967 \\
E. bransiliensis & 50 & 48 & Baker \& Lopez, 1970 \\
E. andinus & 50 & 48 & Bickham, 1979a \\
E. furinalis & 50 & 48 & Baker \& Jordan, 1970 \\
E. lynni & 50 & 48 & Baker \& Paton, 1967 \\
E guadeloupensis & 50 & 48 & Baker \& Paton, 1967 \\
E. diminutus & 50 & 48 & Bickham, 1979a \\
\hline
\end{tabular}

1 One pair of dot-like chromosomes is considered as biarmed, 2 Ando et al. (1977) described this form as Eptesicus japonensis, while according to Wallin (1969) it is a subspecies of E. nilssoni.

telocentric $(\mathrm{NFa}=48)$. Only E. serotinus and E. nilssoni living in Czechoslovakia show some deviation from this pattern, since they have one pair of metacentric dot-like autosomes $(\mathrm{NFa}=50)(\mathrm{Zima}, 1978)$. The only exception to this very ancestral karyotype is Eptesicus capensis, in which 32 chromosomes were found, including 10 pairs of biarmed autosomes (Peterson \& Nagorsen, 1975). Unfortunately, the banding pattern of $E$. capensis chromosomes has not been described, thus we do 
not know which arm combination gave rise to these biarmed autosomes. In addition to such a great difference in the number of chromosomes between $E$. capensis and the other species of Eptesicus, 50 autosome arms were recorded in the former. It would be interesting to know what kind of chromosome no 16/17 occurs in Eptesicus capensis.

Most species of vespertilionid bats are characterized by 50 autosome arms, e.g., most species of the genera Myotis and Pipistrellus, species of the genera Rhogeëssa, Plecotus, Nyctalus, Vespertilio, Miniopterus, and Antrozous. The $\mathrm{NFa}$ variability in vespertilionid bats ranges from 28 (Lasionycteris - Baker \& Patton, 1967; Bickham, 1979a) to 52 (Euderma - Williams et al., 1970). $\mathrm{NFa}=58$ and 60 for two species of Murina are only approximations (Ando et al., 1977) and would seem to be slightly overestimated.

It has been shown that only a very small number of autosome arms in Lasionycteris were formed as a result of various aberrations, mostly tandem fusions, but it is still possible to identify in this genus chromosome segments that are homologous with chromosomes of Eptesicus (Bickham, 1979a).

The present study wholly confirmed the homology of all chromosomes between Eptesicus serotinus and the Nearctic species (E. fuscus and E. lynni). Recently Zima (1982) has found an identical banding pattern in Eptesicus nilssoni. Moreover, the comparison of banding patterns for various species of vespertilionid bats, mostly Nearctic (Anthony \& Kitchin, 1976; Bickham \& Baker, 1977; Bickham \& Hafner, 1978; Bickham, 1979a, b), has revealed that in most cases the evolution of the chromosome pattern occurred through centric fusions. Therefore, the earlier hypothesis (Capanna, 1968b; Capanna \& Civitelli, 1970) that the number of autosome arms equal to 50 , which is characteristic of most vespertilionid bats, reflects Robertsonian processes coupled with the divergence of species has been confirmed.

Bickham (1979a) compared banding patterns of E. fuscus and E. lynni with those in species of the genus Myotis, characterized by four pairs of autosomes in combinations $1 / 2,3 / 4,5 / 6$ and 16/17. Bickham (1979a) found that the first three pairs of biarmed chromosomes are homologous with six acrocentric autosomes of Eptesicus (nos 1-6), while the biarmed autosome no 16/17 in Myotis is homologous with the telocentric autosome in Eptesicus. The morphological difference between chromosomes no $16 / 17$ of these two genera of vespertilionid bats is the result of a pericentric inversion. Therefore the same number (16/17 inv.) was retained for this telocentric autosome in Eptesicus.

However, it is still open to discussion whether in ancestral vespertilionid bats this small chromosome (16/17) was telocentric, as in modern 
Eptesicus, or biarmed as in species of the genus Myotis, that is, whether $\mathrm{NFa}$ of ancestral vespertilionid bats was equal to 50 (as suggested by the frequency of the occurrence of this number in vespertilionid bats) and was then reduced by two units as a result of inversion, or the opposite is true. This can schematically be shown in the form of two competing hypotheses:

$$
\begin{aligned}
& \text { (1) } 16 \text { acro. }+17 \text { acro. } \underset{\text { fusion }}{\longrightarrow} 16 / 17 \mathrm{sm} \stackrel{\text { peric. inv. }}{\longrightarrow} 16 / 17 \text { acro. } \\
& \text { (2) } 16 / 17 \text { acro. } \stackrel{\text { peric. inv. }}{\longrightarrow} 16 / 17 \mathrm{sm}
\end{aligned}
$$

Hypothesis (1) assumes two stages in the evolution of the karyotype in ancestral vespertilionid bats: at the beginning, the number of autosome arms was eqaul to 50 both in the phase of telocentrics nos 16 and 17 and after fusion. Only in the last stage, after a pericentric inversion which reversed the centromere from the submeta position to the acro position, was $\mathrm{NFa}$ reduced to 48 .

Hypothesis (2) is simpler: it assumes the occurrence of only one stage. At first, there was a telocentric chromosome no $16 / 17$ and the number of autosome arms was 48 . Then, after a pericentric inversion, the submetacentric chromosome no $16 / 17$ was formed and $\mathrm{NFa}$ increased to 50 .

Both these hypotheses seem to be reasonable. We may, however, speculate as to which is the more probable. Table 2 shows data on the morphology of chromosomes no $16 / 17$ in vespertilionid bats. In addition to 11 species of the genus Eptesicus, chromosomes no $16 / 17$ also occur in Miniopterus schreibersi, Nycticeius humeralis, Antrozous pallidus, in five species of the genus Lasiurus, and in Lasionycteris noctivagans. In the two last cases, the acrocentric chromosome no $16 / 17$ underwent a tandem fusion with other autosomes. The banded karyotypes of all the species listed above have been analysed, hence there is a high probability of correct identification. Moreover, in Nyctalus leisleri no biarmed autosome of small size was recorded on the basis of conventionally stained material. It should be emphasized, however, that in $N$. leisleri $\mathrm{NFa}=50$, therefore it is possible that this species has two independent telocentric chromosomes nos 16 and 17. Nyctalus leisleri has 46 chromosomes (Fedyk \& Fedyk, 1971; Zima, 1978), while $N$. noctula and $N$. lasiopterus have 42 chromosomes each, and in all three species the number of arms is equal to 50. In the karyotypes of $N$. noctula and $N$. lasiopterus there are small submetacentric chromosomes (Dulić, 1967; Tsuchiya, 1971; Harada, 1973; Ando et al., 1977; Zima, 1978), which could arise as a result of centric fusions, and these are likely to be chromosomes no 16/17. Instead, in Nyctalus furvus an intermediate number of chromosomes was recorded $(2 \mathrm{~N}=44)$, the number of chro- 
mosome arms being 52 (Ando et al., 1977, 1980). This species has two pairs of small biarmed autosomes - submetacentrics and subtelocentrics. One of these pairs may also be the biarmed chromosome no 16/17. These facts may support hypothesis (1) but without the analysis of banding patterns it remains a hypothesis only.

Separate chromosomes nos 16 and 17 were not identified in any species in which G-banding is known. These are either acrocentric chromosomes (examples are given in Table 2) or metacentrics (see

Table 2

Characteristics of chromosomes No. $16 / 17$ in some species of Vespertilionidae. Abbreviations: a - acrocentric, sm - submetacentric, (tr) - translocated chromosome.

\begin{tabular}{|c|c|c|c|c|c|}
\hline Species & $2 \mathrm{~N}$ & $\mathrm{NFa}$ & $\begin{array}{l}\text { Morphology } \\
\text { of chromosome } \\
\text { No } 16 / 17\end{array}$ & Remarks & References \\
\hline $\begin{array}{l}\text { Eptesicus } \\
\text { (11 species) }\end{array}$ & 50 & 48 & a & - & cf. Table 1 \\
\hline $\begin{array}{l}\text { Eptesicus } \\
\text { capensis }\end{array}$ & 32 & 50 & $\mathrm{sm}$ ? & $\begin{array}{l}\text { small sm autosome is } \\
\text { probably homologous to } \\
\text { autosome } 16 / 17\end{array}$ & $\begin{array}{l}\text { Peterson \& } \\
\text { Nagorsen, } 1975\end{array}$ \\
\hline $\begin{array}{l}\text { Histiotus } \\
\text { montanus }\end{array}$ & 50 & 48 & a & - & $\begin{array}{l}\text { Williams \& } \\
\text { Mares, } 1978\end{array}$ \\
\hline $\begin{array}{l}\text { Miniopterus } \\
\text { schreibersi }\end{array}$ & 46 & 50 & $\begin{array}{l}\mathrm{i} \\
\mathrm{n} \\
\mathrm{c}\end{array}$ & $\begin{array}{l}\text { inversion of chromoso- } \\
\text { me No } 10 \text { caused in- } \\
\text { crease of NFa to } 50\end{array}$ & $\begin{array}{l}\text { Bickham \& } \\
\text { Hafner, } 1978\end{array}$ \\
\hline $\begin{array}{l}\text { Nycticeius } \\
\text { humeralis }\end{array}$ & 46 & 48 & a & - & Bickham 1979a \\
\hline $\begin{array}{l}\text { Antrozous } \\
\text { pallidus }\end{array}$ & 46 & 50 & $\begin{array}{l}\mathrm{i} \\
\mathrm{r} \\
\mathrm{r}\end{array}$ & $\begin{array}{l}\text { inversion of chromoso- } \\
\text { me No } 21 \text { caused } \\
\mathrm{NFa}=50\end{array}$ & Bickham 1979a \\
\hline $\begin{array}{l}\text { Lasiurus } \\
(5 \text { species) }\end{array}$ & $26-28$ & 48 & a (tr) & $\begin{array}{l}\text { uniarmed chromosome } \\
\text { No } 16 / 17 \text { was subject } \\
\text { to tandem fusion with } \\
\text { element No } 15 \text { or } 21\end{array}$ & Bickham 1979a \\
\hline $\begin{array}{l}\text { Lasionycteris } \\
\text { noctivagans }\end{array}$ & 20 & 28 & $a(\operatorname{tr})$ & $\begin{array}{l}\text { uniarmed chromosome } \\
\text { no } 16 / 17 \text { was subject to } \\
\text { tandem fusion with } \\
\text { chromosome No } 2\end{array}$ & Bickham 1979a \\
\hline $\begin{array}{l}\text { Nyctalus } \\
\text { leisleri }\end{array}$ & 46 & 50 & $\begin{array}{l}t \\
t \\
a\end{array}$ & $\begin{array}{l}\text { there are no small } \\
\text { twoarmed autosomes at } \\
\text { all }\end{array}$ & $\begin{array}{l}\text { Fedyk \& } \\
\text { Fedyk, 1970; } \\
\text { Zima, 1978 }\end{array}$ \\
\hline
\end{tabular}

Bickham, 1979a, b). As there is no real proof that at any time chromosomes no 16 and 17 were independent acrocentrics, hypothesis (2) should be considered the more probable, especially since the two stages in the evolution of the chromosome pattern assumed by this hypothesis are preserved among karyotypes of modern vespertilionid bats (e.g. Eptesicus and Myotis); it is also possible that the small submetacentric autosome in Eptesicus capensis is chromosome no 16/17. 
It may be suggested, therefore, that the inversion $16 / 17$ acro $\rightarrow 16 / 17$ meta. occurred very early in the evolution of vespertilionid bats, and that this radiation group gave rise to the lineage of Myotini (sensu Tate, 1942). The other genera of vespertilionid bats with the acrocentric chromosome no 16/17 (Table 2) must have evolved independently of the Myotini stem.

The genus Eptesicus is now considered as a complex taxon representing several phyletic radiations of the lineage of pipistrelloids with a reduced number of premolars (Williams \& Mares, 1978). With regard to chromosomes, however, the species of the genus Eptesicus are very conservative; they retained the most ancestral karyotype of vespertilionid bats, the only exception being Eptesicus capensis (Peterson \& Nagorsen, 1975). According to Williams \& Mares (1978), the latter species is an example illustrating phyletic relations between Eptesicus and Pipistrellus. These authors suggest that the karyotype of E. capensis $(2 \mathrm{~N}=32 ; \mathrm{NFa}=50)$ is more similar to that of Pipistrellus nanus $(2 \mathrm{~N}=36 ; \mathrm{NFa}=50$ - Peterson \& Nagorsen, 1975) than to that of P. kuhli $(2 \mathrm{~N}=44 ; \mathrm{NFa}=50$ - Capanna \& Civitelli, 1966; Baker et al., 1974).

The same ancestral chromosome pattern has been recorded in Histiotus montanus $(2 \mathrm{~N}=50 ; \mathrm{NFa}=48$ - Williams \& Mares, 1978); moreover, these authors suggest that the chromosome patterns of Antrozous pallidus and Nycticeius humeralis (see Table 2) evolved directly from the chromosome pattern of Eptesicus.

The advanced evolution of morphological characters (mainly the dental pattern) coupled with the very conservative chromosome pattern provide evidence that the evolution of morphological characters was not synchronized with that of chromosomes in bats. This is not surprising, since various morphological traits (and among them chromosomes) evolve at different rates, or can become stagnant at a certain stage. Thus, the genus Eptesicus preserved the ancestral karyotype though morphologically it is highly modified.

\section{REFERENCES}

1. Ando K., Tagawa T. \& Uchida T. A., 1977: Considerations of karyotypic evolution within Vespertilionidae. Experientia, 33: 877-879.

2. Ando K., Tagawa T. \& Uchida T. A., 1980: The C-banding pattern of 6 Japanese species of vespertilionid bats (Mammalia, Chiroptera). Experientia, 36: $653-654$.

3. Anthony M. C. \& Kitchin R. M., 1976: Sex chromosomes and Giemsa banding pattern of Plecotus townsendii. J. Mammal., 57: 165-166.

4. Baker R. J. \& Patton J. L., 1967: Karyotypes and karyotypic variation of North American vespertilionid bats. J, Mammal., 48; 270-286. 
5. Baker R. J. \& Jordan R. G., 1970: Chromosomal studies of some Neotropical bats of the families Emballonuridae, Noctilionidae, Natalidae and Vespertilionidae. Caryologia, 23: 595-604.

6. Baker R. J. \& Lopez G., 1970: Karyotypic studies of the insular populations of bats on Puerto Rico. Caryologia, 23: 465-472.

7. Baker R. J., Davis B. L., Jordan R. G. \& Binous A., 1974: Karyotypic and morphometric studies of Tunisian mammals: bats. Mammalia, 38: 696-710.

8. Bickham J. W., 1979a: Chromosomal variation and evolutionary relationships of vespertilionid bats. J. Mammal., 60: 350-363.

9. Bickham J. W., 1979b: Banded karyotypes of 11 species of American bats (genus Myotis). Cytologia, 44: 789-797.

10. Bickham J. W. \& Baker R. J., 1977: Implications of chromosomal variation in Rhogeëssa (Chiroptera: Vespertilionidae). J. Mammal., 58: 445-453.

11. Bickham J. W. \& Hafner J. C., 1978: A chromosomal banding study of three species of vespertilionid bats from Yugoslavia. Genetica, 48: $1-3$.

12. Bovey R., 1949: Les chromosomes des chiroptères et des insectivores. Rev. suisse Zool., 56: $371-460$.

13. Capanna E., 1968a: Meccanismi Robertsoniani nell'evoluzione del cariotipo dei Microchirotteri. Boll. Zool., 35: 330-331.

14. Capanna E., 1968b: Some considerations on the evolution of the karyotype of Microchiroptera. Experientia, 24: 624-626.

15. Capanna E. \& Clvitelli M. V., 1966: I cromosomi del pipistrello albolimbato. Caryologia, 19: 231-240:

16. Capanna E. \& Civitelli M. V., 1970: Chromosomal mechanisms in the evolution of chiropteran karyotype. Chromosomal tables of Chiroptera. Caryologia, 23: 79-111.

17. Dulić B., Soldatović B. \& Rimsa D., 1967: La formule chromosomique de la noctule, Nyctalus noctula Schreber (Mammalia Chiroptera). Experientia, 23: 945.

18. Fedyk A. \& Fedyk S., 1970: Karyotypes of some spiecies of vespertilionid bats from Poland. Acta theriol., 15: 295-302.

19. Genoways H. H. \& Baker R. J., 1975: A new species of Eptesicus from Guadeloupe, Lesser Antilles (Chiroptera: Vespertilionidae). Occas. Papers Mus., Texas Tech. Univ., 34: $1-7$.

20. Harada M., 1973: Chromosomes of nine chiropteran species in Japan (Chiroptera). La Kromosomo, 91: 2885-2895.

21. Peterson R. L. \& Nagorsen D. W., 1975: Chromosomes of fifteen species of bats (Chiroptera) from Kenya and Rhodesia. Life Sci. Occ. Paper R. Ontario Mus., 27: 1-16.

22. Seabright M., 1971: A rapid banding technique for human chromosomes. Lancet, 2: $971-972$.

23. Tate G. H. H., 1942: Results of the Archbold expedition No 47. Review of the vespertilioninae bats, with special attention to genera and species of the Archbold collection. Bull. Amer. Mus. Nat. Hist., 80: 221-297.

24. Tsuchiya K., 1971: Chromsomes of two insectivorous bat species from Japan (Chiroptera). J. Mammal. Soc. Jap., 5: 114-116.

25. Tsuchiya K., 1979: A contribution to the chromosome study in Japanese mammals. Proc. Japan Academy, ser. B. 55: 191-195.

26. Wallin L., 1969: The Japanese bat fauna. A comparative study of chorology, 
species diversity and ecological differentiation. Zool. Bidrag, Uppsala, 37: $223-440$.

27. Williams D. F., 1978: Taxonomic and karyologic comments on small brown bats, genus Eptesicus, from South America. Ann. Carnegie Mus., 47: 361-383.

28. Williams D. F., Druecker J. D. \& Black H. L., 1970: The karyotype of Euderma maculatum and comment on the evolution of the plecotine bats. J. Mammal., 51: $602-606$.

29. Williams D. F. \& Mares M. A., 1978: Karyological affinities of the South American big-eared bat, Histiotus montanus (Chiroptera, Vespertilionidae). J. Mammal., 59: 844-846.

30. Zima J., 1978: Chromosome characteristics of Vespertilionidae from Czechoslovakia. Acta Soc. Nat. Brno, 12: 1-38.

31. Zima J., 1982: Chromosomal homology in the complements of bats of the family Vespertilionidae. II. G-band karyotypes of some Myotis, Eptesicus and Pipistrellus species. Folia Zool., 31: 31-36.

Accepted, November 8, 1982.

Stanisław FEDYK \& Andrzej L. RUPRECHT

\section{CHROMOSOMY KILKU GATUNKOW MROCZKOWATYCH. I. WZOR PRAZZKOW NA CHROMOSOMACH EPTESICUS SEROTINUS}

\section{Streszczenie}

Barwienia konwencjonalne i różnicujące chromosomów pozwoliły stwierdzić, że kariotyp mroczka późnego, Eptesicus serotinus (Schreber, 1774) z populacji białowieskiej ma postać $2 \mathrm{~N}=50, \mathrm{NFa}=48$. Kariotyp tego gatunku składa się z 24 par jednoramiennych autosomów; dwuramienne są jedynie chromosomy płci - chromosom $X$ jest submetacentryczny, rozmiarami zbliżony do największej pary autosomów, chromosom Y jest submetacentryczny o rozmiarach dw6ch najmniejszych par autosomów (Fig. 1). Prążkowany kariotyp E. serotinus z północno-wschodniej Polski (Fig. 2) porównano $\mathrm{z}$ danymi z literatury, dotyczącymi dwóch gatunków północnoamerykańskich: Eptesicus fuscus i E. lynni, które posiadają także kariotyp $2 \mathrm{~N}=50, \mathrm{NFa}=48$. Stwierdzono pełną homologię układu prążków chromosomów E. serotinus z chromosomami E. fuscus i E. lynni. Przegląd kariotypów 12 przedstawicieli rodzaju Eptesicus pozwolił stwierdzić, że u większości gatunków są one identyczne (Tabela 1). Przedyskutowano prawdopodobne mechanizmy ewolucji formuly chromosomowej $\mathrm{w}$ obrębie rodziny Vespertilionidae, sprowadzające się do dwóch konkurencyjnych hipotez. Wnioskowano, że kariotyp współczesnych gatunków Eptesicus $(2 \mathrm{~N}=50 ; \mathrm{NFa}=48)$ jest dla całej rodziny najpierwotniejszy (ancetralny). Porównanie chromosomu $\mathrm{nr}$ 16/17 u rozmaitych gatunków Vespertilionidae (Tabela 2) sugeruje, że aberracja dotycząca tej pary chromosomów pojawiła się jako jedna $\mathrm{z}$ pierwszych $\mathrm{w}$ ewolucji formuly chromosomowej całej tej grupy nietoperzy i dała początek linii ewolucyjnej Myotini (sensu Tate, 1942). 


\section{EXPLANATION OF PLATE VII}

Fig. 1. The karyotype of Eptesicus serotinus (male), $2 \mathrm{~N}=50, \mathrm{NFa}=48$.

Fig. 2. Banding pattern of Eptesicus serotinus chromosomes. The chromosomes are numbered after Bickham (1979a). 
1

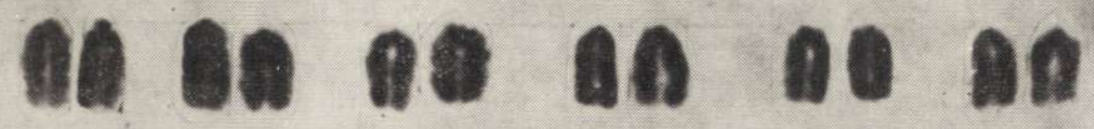

so do oo on an an

AB DA DO Da Ba na

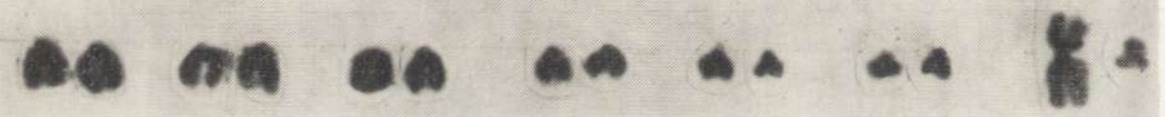

2

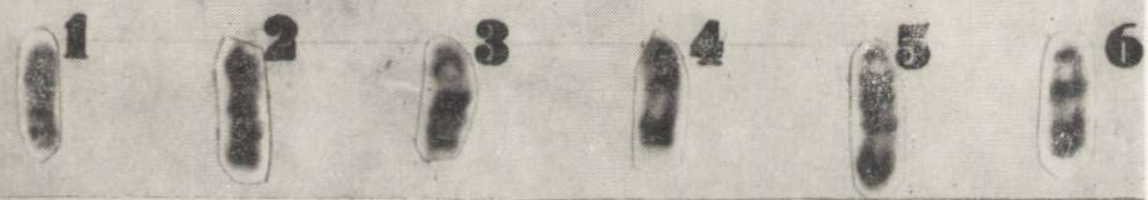

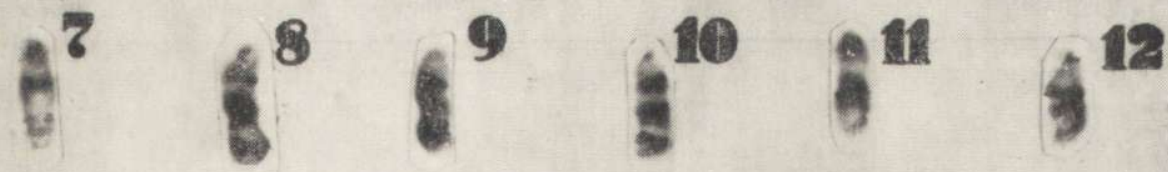

$\left.\left.4^{13}\right)^{15}\right)^{\frac{16}{16}} 8^{18} e^{19}$

$\rightarrow$

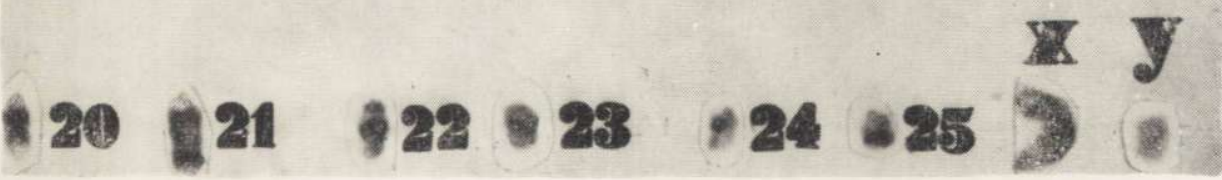

